\title{
ANALYSING THE PERFORMANCES OF ASSET MANAGEMENT COMPANIES OPERATING IN TURKEY BY USING MULTIMOORA METHOD
}

\author{
DOI: 10.17261/Pressacademia.2018.952 \\ JBEF- V.7-ISS.3-2018(3)-p.228-236
}

\section{Burcu Gurol ${ }^{1}$, Adalet Hazar², Cem Bahadir ${ }^{3}$}

${ }^{1}$ Baskent University, Faculty of Commercial Sciences, Banking and Finance Department, Ankara, Turkey. bgurol@baskent.edu.tr, ORCID:0000-0001-9974-2351

${ }^{2}$ Baskent University, Faculty of Commercial Sciences, Banking and Finance Department, Ankara, Turkey. ahazar@baskent.edu.tr, ORCID: 0000-0002-1483-8360

${ }^{3}$ Baskent University, Banking and Finance Department Student

Date Received: July 3, 2018

Date Accepted: September 9, 2018

To cite this document

Gurol, B., Hazar, A., Bahadir, C. (2018). Analysing the performances of asset management companies operating in Turkey by using MULTIMOORA method. Journal of Business, Economics and Finance (JBEF), V.7(3), p.228-236.

Permemant link to this document: http://doi.org/10.17261/Pressacademia.2018.952

Copyright: Published by PressAcademia and limited licenced re-use rights only.

\begin{abstract}
Purpose- In this study, performance improvement of the asset management companies operating in Turkey between 2012 and 2016 is aimed.

Methodology- By analysing the rates calculated with a multi criteria decision making technique, Multimoora, the change in the sectoral performance during 2012,2013,2014,2015 and 2016 is examined.

Findings- As a result of the analysis, it is observed that the sector of asset management companies obtained the highest performance result in 2012, while 2016 has the lowest.

Conclusion- In the years examined, it is clearly seen that the performance level has gone back regularly. No relations have been observed between purchasing rates and performance results of the asset management companies.
\end{abstract}

Keywords: Asset management companies, performance, multi criteria decision-making techniques, MULTIMOORA.

JEL Codes: G20, G22, G23, M40, M49

\section{INTRODUCTION}

Despite the evaluation processes, part of the credits that are given by financial institutions are not paid at due time or in full and become non-performing loans. Since increasing number of non-performing loans leads to the destruction of balance sheet structures and decrease in shareholder's equity, having liquid credits and preventing the increase in non-performing loans are significant for financial institutions. The biggest financial institutions providing credits for those in need are banks. Supervisory and regulatory authorities monitor the degrees of non-performing loans in order to prevent the failure of banks' financial structures that undertake the fund-raising function in the economy. Moreover, they try to ensure that the degrees of non-performing loans stay under certain levels.

Banking Regulation and Supervision Agency (BRSA) has the authority to regulate and supervise the banks in Turkey. The Agency determines the principles related to credit management and makes regulations in order to delimitate nonperforming loans. Non-performing loan is a concept that needs to be followed and monitored under certain levels by banks as well as the other funding institutions such as financial leasing companies, factoring companies and financing companies. Although those companies include it as a part of their activities, the management of non-performing loans is a process that requires labour and time. The non-performing loan volumes that increase especially during crisis periods can turn to a threat for the future of financial institutions.

For funding financial institutions, it is quite difficult to turn non-performing loans to liquid again. Therefore, they can prefer to distract those credits from their financial tables. One way to do that is to transfer the non-performing loan portfolio to an 
asset management company. Asset management companies are such institutions that can purchase, sell, collect the receivables they bought, liquidate, restructure and sell their assets with their receivables coming from the relevant services of banks, Saving Deposit Insurance Fund, other financial institutions and insurance companies that provide credit insurance service. Asset management companies ensure the payment of debt by getting in contact with the obligors of nonperforming loan portfolios they bought, granting discounts in the obligation of funds, as well as providing a payable redemption plan for the obligor. In this way, obligations that have no/low possibility of being received are collected and obligors are saved from the legal restrictions originating from their unpaid obligations.

The first regulation regarding the establishment and activities of asset management companies in Turkey was made in 2002 by Banking Regulation and Supervision Agency. The reasons of that regulation were the financial crisis in Turkey leading to the increase in non-performing loan balances in bank balance sheets and that was the negative situation's turning into a threat for the regulation of banks. With this regulation, banks decided to reduce the pressure among themselves by selling their non-performing credit portfolios to the established asset management companies. The number of asset management companies, which were established and came into operation after the regulation in 2002 have increased within the process.

\section{LITERATURE REVIEW}

In literature, the first studies related to the asset management companies concentrate upon the effects of asset management companies on deferred credit rates. In his study by acquiring data from reports regarding Asset Management Companies, annual company reports and World Bank Reports, Klingebiel examines whether asset management companies in 7 countries have accomplished their goals or not. In the end of the study, it is declared that in Spain the results are positive while being negative in Mexico. In the remaining part of the study, no clear finding regarding the accomplishment of goals was obtained (Klingebiel, 2001). Mesutoğlu studies the liquidation of non-performing loans by asset management companies with examples. In addition, he states that the asset management companies' chance of success would increase by internal as well as external factors (Mesutoğlu, 2001).

Hagiwara and Pasadilla concluded that while the existence of asset management companies have increased the nonperforming loan rate in Thailand, Thailand Asset Management Company- which is a government institution- has decreased the non-performing loan rates of the banks. In the same study, they observe that the new legal proceedings against banks and other financial institutions have decreased significantly (2004). In their study Fung, George, Hohl and Ma (2004) examine the common features of and the differences between the public asset management companies in Asia. The study deals with the establishment of asset management companies in each country, the transfer of troubled assets to those companies, solutions regarding the troubled assets and financing. As the final outcome, it is emphasized in the study that the asset management companies are significant for the stability of financial system and the solutions of problems related to the banking system (2004). In the study conducted by Selimler, the liquidation of non-performing loans by asset management companies in Turkish banking sector is examined and the practices of asset management companies in chosen countries and Turkey are evaluated. It is concluded that the countries examined have succeeded in achieving their goals in general by means of the asset management companies. In addition, it is stated that those assets troubled in terms of pricing constitute a new value between their purchase and sale prices (2006).

Inogucci concludes that in Malaysia and Thailand, with the establishment of asset management companies by the state following the crisis, non-performing loan rate has decreased, Macro-Economic conditions affected their decline and the banks performing well had low rates of non-performing loans during the crisis (Inogucci, 2012). Hazar and Babuşcu suggest a method of calculating the net present value of receivables portfolio during the sale of receivables to the asset management companies (2013). No studies regarding the performance measurements of asset management companies have been found in the literature.

\section{DATA AND METHODOLOGY}

\subsection{Data}

This study was conducted with data obtained from the financial statements of asset management companies, operating between 2012 and 2016 in Turkey. Table 1 demonstrates the list of the asset management companies operating in the years examined by this study. 
Table 1: The List of Asset Management Companies Operating Between 2012 and 2016 in Turkey

\begin{tabular}{|l|l|l|l|l|}
\hline $\mathbf{2 0 1 2}$ & $\mathbf{2 0 1 3}$ & $\mathbf{2 0 1 4}$ & $\mathbf{2 0 1 5}$ & $\mathbf{2 0 1 6}$ \\
\hline Anadolu & Anadolu & Artı & Artı & Bebek \\
Bebek & Bebek & Bebek & Atlas & Birleşim \\
Efes & Deniz & Destek & Bebek & Destek \\
Final & Efes & Efes & Destek & Efes \\
Girişim & Final & Final & Efes & Final \\
İstanbul & Girişim & Girişim & Güven & Hayat \\
LBT & İstanbul & İstanbul & İstanbul & Hedef \\
RCT & RCT & Turkasset & Mega & İstanbul \\
& RCT & Vera & RCT & Mega \\
& Turkasset & & Sümer & RCT \\
& Vera & & Turkasset & Tümer \\
& & & & Turkasset \\
& & & & Vera \\
& & & & Yunus \\
\hline
\end{tabular}

Source: https://www.bddk.org.tr

It is observed that together with the rise in the number of asset management companies, total assets balance of the sector has also increased. The active developments of operating asset management companies are shown in Table $\mathbf{2}$.

Table 2: Total Size of Assets of the Asset Management Companies That Operate in Turkey

\begin{tabular}{|l|l|l|l|l|}
\hline $\mathbf{2 0 1 2}$ & $\mathbf{2 0 1 3}$ & $\mathbf{2 0 1 4}$ & $\mathbf{2 0 1 5}$ & $\mathbf{2 0 1 6}$ \\
\hline 1.429 .609 .000 & 1.853 .465 .000 & 2.546 .470 .000 & 2.770 .548 .000 & 3.211 .002 .000 \\
\hline
\end{tabular}

In this study, financial performance development of asset management companies operated between 2012 and 2016 in Turkey is analysed by using a decision-making method, MULTIMOORA.

\subsection{Multi Criteria Decision Making and MULTIMOORA Method}

Multi criteria decision making is a structure that combines methods where multiple disciplines such as mathematics, management, informatics, psychology, social sciences and economics come together and provide the opportunity to evaluate and decide on multiple decision problems to the researcher (Turan, 2015).

The name of MOORA method, which is one of the multi criteria decision-making techniques, comes from the first letters of the following words: "Multi Objective Optimization by Ratio Analysis". The method was developed by Willem Karel M. Brauers and Edmundas Kazimieras Zavadskas and was published with an article in 2006.

Karaca specifies the distinguished features that bring MOORA method forward in three items in her Master Thesis:

- Taking all goals into consideration and evaluation,

- Considering all the interactions between alternatives and goals not in parts, but simultaneously,

- Using nonsubjective scalar values instead of subjective weighted normalization (Karaca, 2011).

MOORA method starts with the composition of the decision matrix. The decision matrix consists of alternatives as well as the factor values related to these alternatives. The factors are the criteria determined by the person who applies this method and wants to identify the alternatives.

$$
x_{i j}=\left[\begin{array}{ccc}
x_{11} x_{12} & \ldots & x_{1 n} \\
x_{21} x_{22} & \ldots & x_{2 n} \\
\cdot & \\
\cdot & \\
\cdot & \\
x_{m 1} x_{m 2} & \ldots & x_{m n}
\end{array}\right]
$$

MOORA method starting from the composition of the decision matrix is completed by interpreting the rankings obtained via ratio system and reference point approach described below. 
In 2010, Brauers and Zvadskas added the full multiplicative form to the existing MOORA method and developed the MULTIMOORA method where the real result is obtained by evaluating the results of reference point approach as well as the full multiplicative form. Figure 1 represents the MULTIMOORA method.

Figure 1: MULTIMOORA (Bekar, 2014).

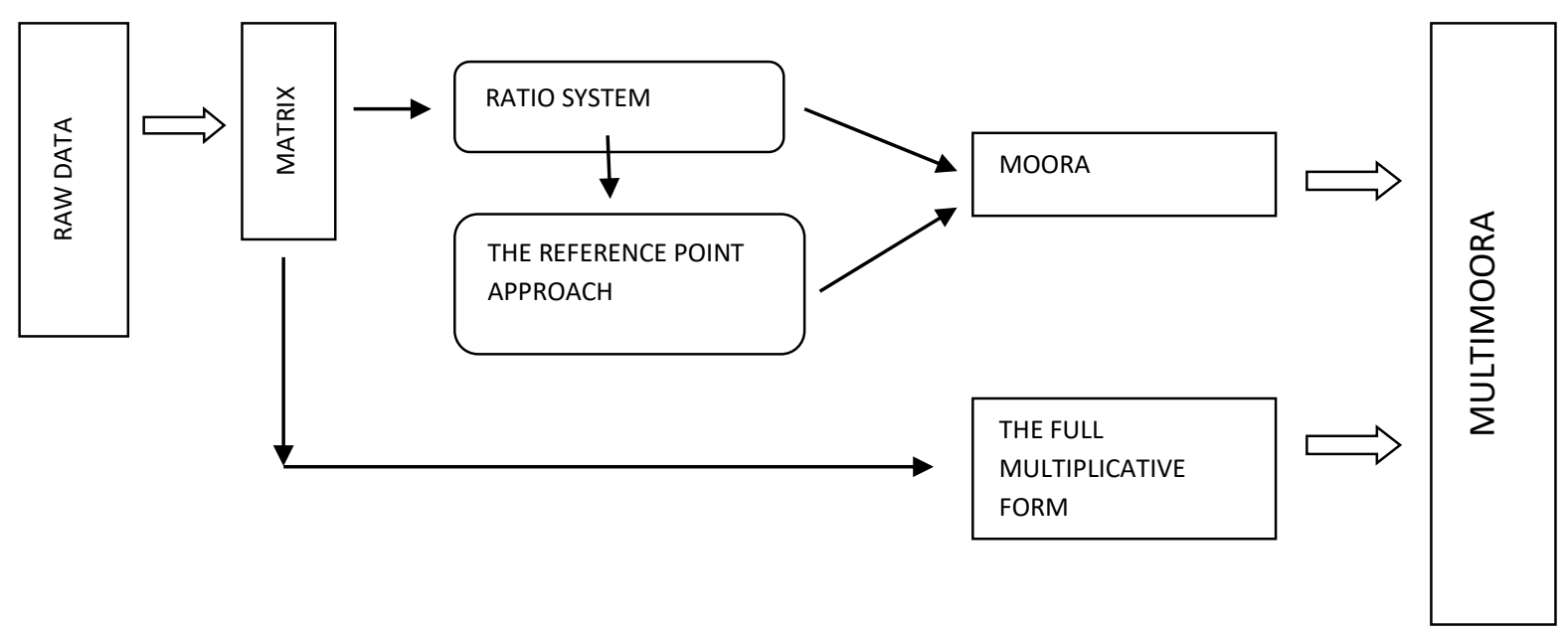

As it can be seen from Figure 1, MULTIMOORA Method gives the opportunity to rank the alternatives to the researcher by considering the results of Ratio System, Reference Point Approach and The Full Multiplicative Approach.

\subsubsection{Ratio Method}

In Ratio System, a new matrix is created by calculating the ratio of each value in the decision matrix to the value found by taking the square root of the sum of the squares of each value in the relevant criterion.

$$
\frac{X_{i j}}{\sqrt{\sum_{i=1}^{m} x_{i j}^{2}}}
$$

In this way, every value partaking in the decision matrix is normalized. Normalization is done in order to prevent the differences between values from affecting the results in a misleading way.

$$
x_{i j}^{*}=\frac{x_{i j}}{\sqrt{\sum_{i=1}^{m} x_{i j}^{2}}}
$$

The researcher wants to include some of the criteria in the normalized matrix as maximum and some others as minimum.

For example, if the study is conducted in order to decide to purchase the fittest one among different houses, the decision maker would prefer the distance from the centre at a minimum, house size to the utmost and the price at a minimum. For this reason, we need to determine how to include each criterion to the decision, namely to the utmost or at a minimum.

Following this step, the sum of criteria included at a minimum are subtracted from the sum of criteria included to the utmost for each alternative. By this, results showing the place of each alternative in the final ranking is obtained.

$$
y_{i}=\sum_{j}^{g} x_{i j}^{*}-\sum_{j=g+1}^{n} x_{i j}^{*}
$$

\subsubsection{The Reference Point Method}

The reference point approach is based on the ratio system approach. In addition to the ratio system, here the maximum goal reference point approach is valid and this approach has a realistic and nonsubjective structure (Çelebi, 2014).

While applying reference point method, for each factor among the values in the normalized matrix, we determine the highest value if it is a value to be maximized or the lowest one if it is a value to be minimized as a reference value $\left(r_{j}\right)$. 
After determining reference values, we use the distance from the determined reference point for the criterion of each value partaking in the normalized matrix as a base in order to determine its place in the ranking according to the reference point method.

$\left(r_{j}-x_{i j}^{*}\right)$

$\min _{i}\left(\max _{j}\left|r j-x_{i j}^{*}\right|\right)$

\subsubsection{The Full Multiplicative Form Method}

In the full multiplicative form, the values to be maximized and the values to be minimized partaking in the decision matrix are multiplied by themselves for each alternative.

$A_{j}=\Pi_{i=1}^{g} x_{i j}$

$B_{j}=\prod_{i=g+1}^{n} x_{i j}$

With the results obtained through the division of the multiplication of the values to be maximized by the multiplication of the values to be minimized, the place of each alternative in the final ranking is determined.

$U_{J}^{\dot{\mathrm{I}}}=\frac{A_{j}}{B_{j}}$

\subsubsection{Making MULTIMOORA Ranking}

In MULTIMOORA method, the results obtained from ratio system, reference point approach and the full multiplicative form are ranked. According to the dominance comparison, via the rankings of these 3 methods, the final MULTIMOORA ranking results are obtained.

\section{ANALYSIS}

The financial ratios demonstrated in Table 3 are included in the calculation during the application of this method. By summing the balances of relevant booking items partaking in the independent audit reports of the institutions that operate as asset management companies in the relevant year, sector averages are obtained. In addition, the ratios are calculated by using these balances.

Table 3: Financial Ratios Used in This Study

\begin{tabular}{|l|}
\hline Receivables/Shareholders Equity: This ratio shows how much receivables is created with current equity \\
\hline Interest Income/ Interest Expense: This ratio shows how much interest is paid when interest income is gained. \\
\hline Operating Income/Total Assets: This ratio shows how much operating income is earned with total assets. \\
\hline Net Interest Income/ Shareholders Equity: This ratio shows how much net interest income is earned with current equity \\
\hline Loans/ Shareholders Equity: This ratio indicates the ratio of bank loans to equity \\
\hline Banks/ Shareholders Equity: This ratio shows how much of the equity is in liquid assets \\
\hline Loans/Total Assets: This ratio indicates the ratio of bank loans to total assets \\
\hline Receivables/Total Assets: This ratio indicates the share of receivables in total assets \\
\hline Banks/Total Assets: This ratio indicates the share of bank deposits in total assets \\
\hline Net Profit /Operating Income: This rate shows how much of the operating income is earned as profit. \\
\hline Net Profit /Total Assets: This ratio shows how much profit is made with total assets. \\
\hline
\end{tabular}

The values of the ratios in Table $\mathbf{3}$ by years are formed into a decision matrix in Table 4 
Table 4: Decision Matrix

\begin{tabular}{|c|c|c|c|c|c|c|c|c|c|c|c|}
\hline & Max & Max & Max & Max & Min & Max & Min & Max & Max & Max & Max \\
\hline & 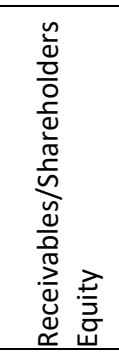 & 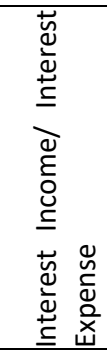 & 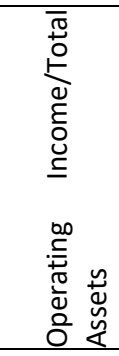 & 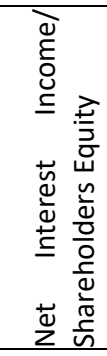 & 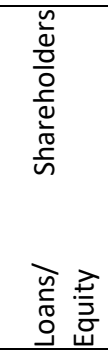 & 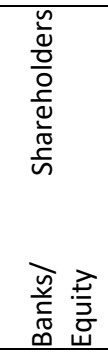 & 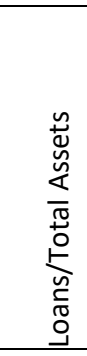 & 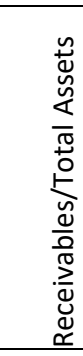 & 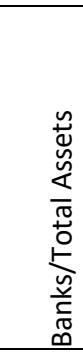 & 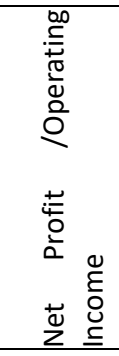 & 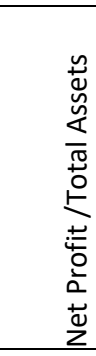 \\
\hline 2012 & 2,54 & 5,59 & 0,90 & 0,65 & 1,97 & 0,42 & 0,64 & 0,82 & 0,14 & 0,32 & 0,09 \\
\hline 2013 & 2,97 & 5,64 & 0,92 & 0,97 & 2,56 & 0,56 & 0,69 & 0,80 & 0,15 & 0,10 & 0,02 \\
\hline 2014 & 3,54 & 4,40 & 1,00 & 0,96 & 3,33 & 0,41 & 0,75 & 0,80 & 0,09 & 0,16 & 0,04 \\
\hline 2015 & 2,80 & 4,02 & 0,92 & 0,81 & 2,39 & 0,29 & 0,68 & 0,80 & 0,08 & 0,15 & 0,04 \\
\hline 2016 & 2,93 & 4,21 & 0,85 & 0,80 & 2,48 & 0,18 & 0,69 & 0,81 & 0,05 & 0,12 & 0,03 \\
\hline
\end{tabular}

Normalization is applied in order to prevent differences between the values in the decision matrix from changing the results of analysis in a misleading way. After that, the normalized matrix represented by Table $\mathbf{5}$ is obtained.

Table 5: Normalized Matrix

\begin{tabular}{|c|c|c|c|c|c|c|c|c|c|c|c|}
\hline & 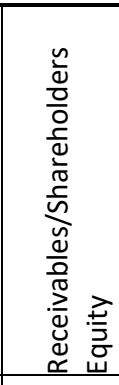 & 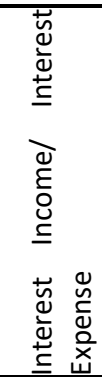 & 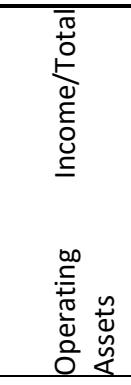 & 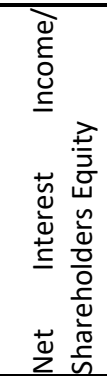 & 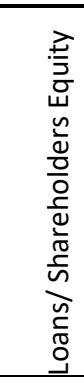 & 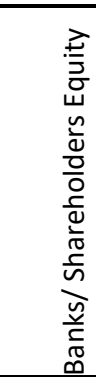 & 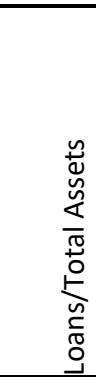 & 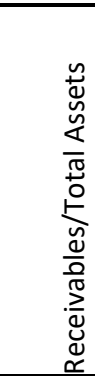 & 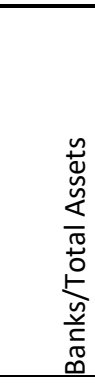 & 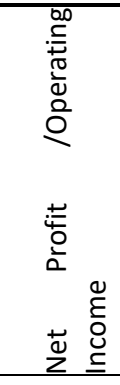 & 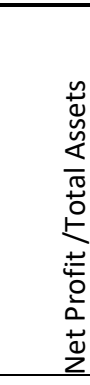 \\
\hline 2012 & 0,38 & 0,52 & 0,44 & 0,34 & 0,34 & 0,48 & 0,41 & 0,46 & 0,56 & 0,76 & 0,81 \\
\hline 2013 & 0,45 & 0,52 & 0,45 & 0,51 & 0,44 & 0,64 & 0,45 & 0,44 & 0,62 & 0,24 & 0,22 \\
\hline 2014 & 0,53 & 0,41 & 0,49 & 0,51 & 0,58 & 0,47 & 0,49 & 0,44 & 0,38 & 0,38 & 0,31 \\
\hline 2015 & 0,42 & 0,37 & 0,45 & 0,43 & 0,41 & 0,33 & 0,44 & 0,44 & 0,34 & 0,36 & 0,35 \\
\hline 2016 & 0,44 & 0,39 & 0,41 & 0,42 & 0,43 & 0,20 & 0,45 & 0,45 & 0,20 & 0,30 & 0,26 \\
\hline
\end{tabular}

According to the ratio system-the first method in Multimoora-the ratio value of each year is calculated by subtracting the sum of values to be minimized from the sum of values to be maximized and the ranking according to the ratio system is obtained. See Table 6.

Table 6: Values for Each Year Calculated by Ratio Method and Ranking Results

\begin{tabular}{|l|l|l|}
\hline 2012 & 3,9944 & $\mathbf{1}$ \\
\hline 2013 & 3,1913 & $\mathbf{2}$ \\
\hline 2014 & 2,8561 & $\mathbf{3}$ \\
\hline 2015 & 2,6504 & $\mathbf{4}$ \\
\hline 2016 & 2,2019 & $\mathbf{5}$ \\
\hline
\end{tabular}


In order to rank according to the reference point approach, each year's reference value should be determined. Our references are the highest values for the rates to be maximized in the normalized matrix and the lowest ones fort he rates to be minimized. The reference values based on the values in normalized matrix are demonstrated in Table 7.

Table 7: Reference Points

\begin{tabular}{|c|c|c|c|c|c|c|c|c|c|c|c|}
\hline & 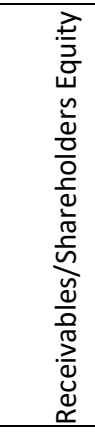 & 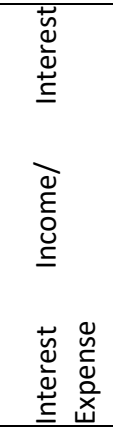 & 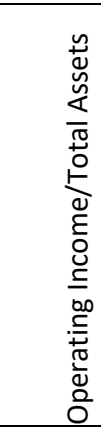 & 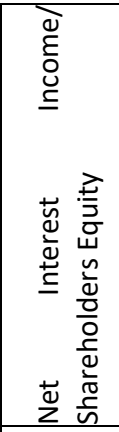 & 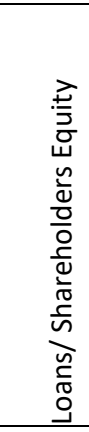 & 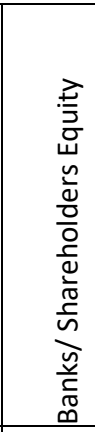 & 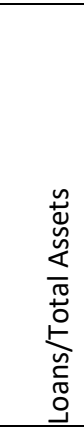 & 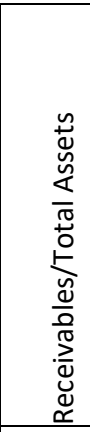 & 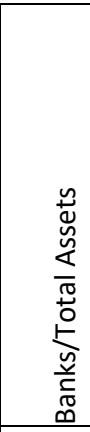 & 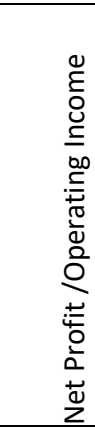 & 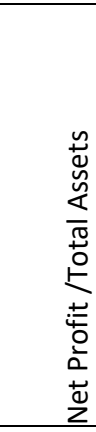 \\
\hline $\begin{array}{l}\text { Reference } \\
\text { Points }\end{array}$ & 0,53 & 0,52 & 0,49 & 0,51 & 0,34 & 0,64 & 0,41 & 0,46 & 0,62 & 0,76 & 0,81 \\
\hline
\end{tabular}

By calculating the absolute value of the distance of each year's value in the normalized matrix from the relevant reference value, a new matrix is created. In this matrix, by subtracting the minimum distance from the reference point from the maximum for each year, value and ranking of each year according to the reference point approach are obtained. The values calculated according to the reference point approach and the ranking results are shown in Table 8.

Table 8. Values by the years according to the reference point method and ranking results

\begin{tabular}{|l|l|l|}
\hline 2012 & 0,1675 & $\mathbf{1}$ \\
\hline 2013 & 0,5980 & $\mathbf{5}$ \\
\hline 2014 & 0,5005 & $\mathbf{3}$ \\
\hline 2015 & 0,4610 & $\mathbf{2}$ \\
\hline 2016 & 0,5560 & $\mathbf{4}$ \\
\hline
\end{tabular}

In order to get the results of the full multiplicative form, which is the last approach of Multimoora method, multiplication of the values of the decision matrix to be maximized is rated to the multiplication of the values to be minimized. For the values of each year obtained s a result of that proportioning and the ranking results, see Table 9.

Table 9. Values by the years according to the full multiplicative form and ranking results

\begin{tabular}{|l|l|l|}
\hline 2012 & 0,0088 & 1 \\
\hline 2013 & 0,0013 & 2 \\
\hline 2014 & 0,0010 & 3 \\
\hline 2015 & 0,0006 & 4 \\
\hline 2016 & 0,0001 & 5 \\
\hline
\end{tabular}

See Table 10 for 3 performance ranking results that are obtained by applying ratio, reference point and the full multiplicative approaches for the years examined .By Multimoora method, in order to reach to the final ranking, the results should be sorted by their dominance first. Those results are shown in Table 10, as well. 
Table 10: Ranking Results Obtained from the Approaches Applied and the Results Of Multimoora Method

\begin{tabular}{|l|l|l|l|l|}
\hline & $\begin{array}{l}\text { Ratio Method } \\
\text { Ranking }\end{array}$ & $\begin{array}{l}\text { Reference Method } \\
\text { Ranking }\end{array}$ & $\begin{array}{l}\text { The Full Multiplicative } \\
\text { Method Ranking }\end{array}$ & Multimoora Ranking \\
\hline 2012 & 1 & 1 & 1 & 1 \\
\hline 2013 & 2 & 5 & 2 & 2 \\
\hline 2014 & 3 & 3 & 3 & 3 \\
\hline 2015 & 4 & 2 & 4 & 4 \\
\hline 2016 & 5 & 4 & 5 & 5 \\
\hline
\end{tabular}

\section{FINDINGS AND DISCUSSIONS}

In this study, by using balances that are the sum of the relevant account balances in the independent audit reports of asset management companies operating in Turkey, the financial rates of the sector are calculated. By analysing the rates calculated with a multi criteria decision making technique, Multimoora, the change in the sectoral performance during 2012, 2013, 2014, 2015 and 2016 is examined. As a result of the analysis, it is observed that the sector of asset management companies obtained the highest performance result in 2012, while 2016 has the lowest. In the years examined, it is clearly seen that the performance level has deteriorated regularly. The reasons could be the increase in the number of the asset management companies, which started to operate in 2002 in our country, the increase in the level of competition accordingly and asset management companies' doing their purchases with higher ratios. Therefore, Table $\mathbf{1 1}$ is created to show the sale values that the sector have paid for the given amounts of receivables.

Table 11: Amounts of Troubled Receivables Purchased by the Asset Management Companies During the Years Examined and Purchasing Rates

\begin{tabular}{|l|l|l|l|}
\hline & $\begin{array}{l}\text { Total Amount of the } \\
\text { Receivables }\end{array}$ & Sale Value of the Receivables & Purchasing Rate \\
\hline $\mathbf{2 0 1 2}$ & $2.117 .780 .005,00$ & $306.408 .060,00$ & 0,145 \\
\hline $\mathbf{2 0 1 3}$ & $2.745 .307 .991,00$ & $409.426 .511,00$ & 0,149 \\
\hline $\mathbf{2 0 1 4}$ & $4.449 .734 .770,83$ & $668.315 .595,00$ & 0,150 \\
\hline $\mathbf{2 0 1 5}$ & $1.670 .847 .157,00$ & $269.431 .000,00$ & 0,161 \\
\hline $\mathbf{2 0 1 6}$ & $5.447 .215 .926,00$ & $547.826 .909,00$ & 0,101 \\
\hline
\end{tabular}

While the sector purchased the non-performing receivables by paying $14,5 \%$ on average in 2012 , the rate increased to $16 \%$ in 2015. For this reason, it is thought that there can be a relationship between the purchasing rates and the decrease in performance results. On the contrary to this situation, although purchasing by the lowest rate was in 2016, the performance results of 2016 was the poorest.

\section{CONCLUSION}

In this study, the performance of asset management sector in Turkey was examined and has the following conclusions were reached. It is observed that the sector of asset management companies obtained the highest performance result in 2012, while 2016 has the lowest. In the years examined, it is clearly seen that the performance level has derogated regularly. The sector has purchased in increasing rates in 2012, 2013, 2014 and 2015 while purchasing the non-performing receivables. While the sector purchased the non-performing receivables by paying $14,5 \%$ averagely in 2012 , the rate increased to $16 \%$ in 2015.

For this reason, it is thought that a relationship can be found between the purchasing rates and the decrease in performance results. On the contrary to this situation, although purchasing by the lowest rate was in 2016, the performance results of 2016 was the worst. Therefore, it is not possible to demonstrate this relationship with the existing data. Because there are multiple, internal and external factors effecting the performances of the financial institutions. Among those factors, besides competition, we could count such elements as the progress in market interest rates, inflation, growing of the economy, technological factors etc. conducting the analysis by taking these factors into account, can take this study to a further level. 


\section{REFERENCES}

Babuşcu, Ş., Hazar, A. (2013). Varlık yönetim şirketlerine satilacak takipteki krediler için değerleme: varsayimsal bir yaklaşım. World of Accounting Science, 153-175.

Bekar, M. (2014, Kasım). 2008-2013 döneminde Türk bankacilik sektörünün etkinliğinin VZA, Malmquist TFP endeksi ve Multimoora yöntemi ile incelenmesi. 44. Ankara.

Çelebi, B. (2014, Haziran). Proje tipi bir işletmede 2-tuple Multimoora yöntemi ile tedarikçi seçimi. Proje Tipi Bir İşletmede 2-Tuple Multimoora Yöntemi ile Tedarikçi Seçimi . Ankara.

Fung, B., George, J., Hohl, S., Ma, G. (2004). Public asset management companies in East Asia . Bank of International Settlement.

Hagiwara, A. T., Passadilla, G. (2004). Experience of Asian asset management companies: do they increase moral hazard?- Evidence from Thailand. ERD Working Paper.

Inogucci, M. (2012). Nonperforming loans and public asset management companies in Malaysia and Thailand. Asia Pacific Economic Research, 1-30.

Karaca, T. (2011, 06 16). Proje yönetiminde çok kriterli karar verme tekniklerini kullanarak kritik yolun bulunması. 23-24. Ankara.

Klingebiel, D. (2001). The use of asset management companies in the resolution of banking crises cross country experiences. World Bank Policy Research Working Paper Series.

Mesutoğlu, B. (2001). Sorunlu aktiflerin varlik yönetimi şirketlerince tasfiyesi- ülke örnekleri-. Ankara: Bankacılık Düzenleme ve Denetleme Kurumu.

Selimler, H. (2006). Türk bankacilik sektöründe sorunlu kredilerin varlik yönetim şirketlerince tasfiyesi, seçilmiş ülkeler ve Türkiye uygulaması. 298. İstanbul.

Turan, G. (2015). Çok kriterli karar verme. In B. F. Yıldırım, \& E. Önder, Çok Kriterli Karar Verme Yöntemleri (p. 15). Bursa : Dora Yayınevi. 